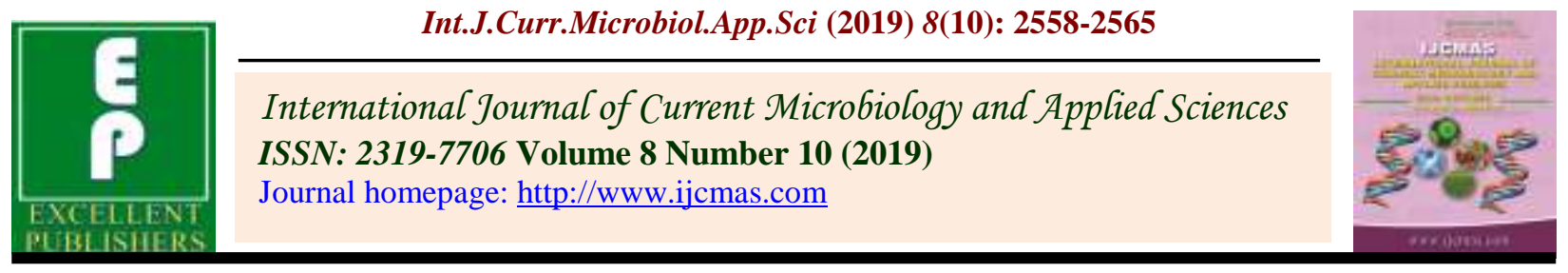

Original Research Article

https://doi.org/10.20546/ijcmas.2019.810.296

\title{
Adaptogenic (Anti-Stress) Effect of Aqueous Musanga cecropioides (Urticaceae)
}

\author{
Tunde A. Owolabi ${ }^{1,2^{*}}$, K.C. Ezenwa ${ }^{1}$, E.Y. Olayioye ${ }^{1}$, O.C. Iyorhibe ${ }^{1}$, E. Amodu ${ }^{1}$, \\ O.F. Aferuan ${ }^{1}$, P.C. Okubor ${ }^{3}$, B.A. Ayinde ${ }^{2}$ and J.I. Okogun ${ }^{1}$ \\ ${ }^{1}$ Research Unit, Paxherbal Clinic and Research Laboratories, Edo state, Nigeria \\ ${ }^{2}$ Pharmacognosy department, University of Benin, Benin City, Edo State, Nigeria \\ ${ }^{3}$ Department of Biology, College of Education, Agbor, Delta state, Nigeria \\ *Corresponding author
}

Keywords

Anti-stress, Anti-

oxidant, Musanga

cecropioides

Article Info

Accepted:

18 September 2019

Available Online:

10 October 2019

\section{A B S T R A C T}

Everyone tries to relieve stress by taking anti-stress drugs. However, synthetic anti-stress drugs have unwanted side effects, expensive and not readily accessible. Thus, we aimed at investigating the anti-stress activities of aqueous extract of Musanga cecropioides stem bark using forced swimming endurance stress test, anoxia stress tolerance, chronic cold resistance stress test and DPPH radical scavenging capacity. Daily administration of aqueous extract of $M$. cecropioides at doses of 100,200 and $300 \mathrm{mg} / \mathrm{kg}$ bodyweight one hour prior to induction of stress, at the lowest dosage $(100 \mathrm{mg} / \mathrm{kg})$ significantly increased the anoxia stress and forced swimming endurance stress tolerance times in a dose dependent manner as compared to the control groups $(46.48 \pm 0.28$ and $3.01 \pm 0.92$ compared $28.80 \pm 0.38$ and $2.25 \pm 0.08$ mins), the blood glucose, blood cells, and the urinary ascorbic acid were normalised in all the tested methods including chronic cold stress. The extract also scavenged DPPH significantly in a dose dependent manner. The results showed impressive anti-stress potential and present as far as is known, the first report of the antistress (adaptogenic) activities of $M$. cecropioides.

\section{Introduction}

Stress can be termed as the summation of all the reactions of the body, which destabilises the normal physiological condition resulting in a state of threatened homeostasis. Stress is internationally recognized as phenomenon caused by advancement of industrialization in a demanding civilization. Stress represents a reaction of the body to a stimulus that tends to alter its normal physiological equilibrium or homeostasis (Selye, 1998). Adaptogens (antistress) could be chemically or naturally derived active entities which induce nonspecific responses that increase the resistance of an organism to a state stress (Ahmad et al., 1998). Most of which are scientifically unproven, yet marketed as a supplement to increase resistance to stress, trauma, anxiety and fatigue, hence it is imperative that such 
claim be subjected to scientific studies. This study was aimed at investigating the antistress effect of aqueous extract M.cecropioide of its many biological activities. Supplements with various natural recipes have been evaluated for their adaptogenic activity during exposure to stressful environmental conditions (Kenjale et al., 2007) but nothing of such on $M$. cecropioide.

M. cecropioides is an evergreen straight stemmed tree up to $18 \mathrm{~m}$ tall. The tree's crown is umbrella-like, with very stout and pithy branchlets producing no latex (Orwaet al., 2009). Traditionally, the plant is used to induce labour, reduce elevated blood pressure and also to reduce high blood sugar (Irvine, 1961), anthelmintic and antidysentric (Gill, 1992), treatment of fever, jaundice, acute gastric poisonings and liver diseases (Bunkill, 1985).

Phytochemical studies have reported the presence of kalaic acid stem bark and some other triterpenoid acids in the leaves stem bark and the root wood (Lontsi et al., 1998). Protocatechuic acid (3,4-dihydroxybenzoic acid) and protocatechualdehyde (3,4dihydroxybenzaldehyde were obtained from the stem bark of the plant (Ayinde et al., 2007).

Reported biological activities of the plant include; uterotonic (Kamanyi et al., 1992), antidiabetic (Adeneye et al., 2007), hypotensive (Ayinde et al., 2003; Adeneye et al., 2006; Ayinde et al., 2009; Dongmo et al., 1996), Oxytocic effects (Ayinde et al., 2006) etc.

\section{Materials and Methods}

\section{Plant materials}

The fresh stem bark of the $M$. cecropioides was collected within the locality of Ewu town, Esan LGA, Edo state, Nigeria in the month of May, 2016. The plant was identified and authenticated by Mr. E.A Emmanuel (of Professor J.C. Okafor Herbarium, Pax Herbal Clinic and Research Laboratories, Ewu, Nigeria) and voucher specimen compared with Herbarium sample in the department of pharmacognosy, University of Benin, Benin city.

\section{Plant processing and preparation of extract}

The bark was cut into smaller pieces and airdried at room temperature for a period of 14 days. Thereafter, they were transferred into an oven maintained at $50^{\circ} \mathrm{C}$ for another 2 days before pulverised into powder using an electric milling machine (Chris Norris, England).

The powdered stem bark $(2 \mathrm{~kg}) \quad M$. cecropioides was gradually extracted with distilled water (4L) using decoction method for $30 \mathrm{~min}$. The extract obtained was concentrated on electrothermal constant water bath (Model DK-8A) to obtain a brown semisolid paste which was stored in sample bottles kept in refrigerator $\left(4^{\circ} \mathrm{C}\right)$ for further use.

\section{Chemicals used}

All chemical and reagent used are of analytical grade obtained from Pax herbal clinic and research laboratories.

\section{Experimental animal grouping}

The rats were randomly divided into 5 groups (1-5) of 6 rats as follows;

Group 1 Unstressed control group and were given only distilled water

Group 2 Stressed control group and were given only distilled water 
Group 3 Rats were given standard drug (diazepam) $1 \mathrm{mg} / \mathrm{kg}$

Group 4 Rats were given $200 \mathrm{mg} / \mathrm{kg}$ of $M$. cecropioides extract

Group 5 Rats were given $400 \mathrm{mg} / \mathrm{kg}$ of $M$. cecropioides extract.

\section{Forced swimming endurance stress test}

Swiss albino mice (18-25g) were used for forced for forced swim endurance stress test. The animals were divided into 5 groups and all were treated as mentioned above in scheduled drug treatments. The drug treatment was given continuously for seven days (same dose daily). On the 8th day the mice were subjected to swimming stress by keeping them in polypropylene tank of dimension $37 \times 37 \times 30 \mathrm{~cm}$ filled with water to a height $25 \mathrm{~cm}$. Mice were allowed to swim till complete exhaustion and the end point was taken when animal starting drowning. The mean swimming time for each group was calculated. The blood was collected through retroorbital puncture to estimate biochemical parameters like Serum glucose, Corticosterone and blood cells (Puri et al., 2011).

\section{Chronic cold resistant stress test}

Swiss albino mice $(18-25 \mathrm{~g})$ were used for forced for chronic cold resistant stress test. The animals were divided into 5 groups and all were treated as mentioned above in scheduled drug treatments. The drug treatment was given continuously for seven days (same dose daily). In Each animals were subjected to cold stress by exposing them to 4 $\pm 10^{\circ} \mathrm{C}$ daily for 2 hours. The extracts were administered daily once to respective groups. This procedure was repeated for a period of 7 days. Blood was collected through orbital plexus under light ether anaesthesia to estimate biochemical parameters like blood glucose, corticosteroid, and blood cell count (RBC and WBC). Animals were sacrificed by giving excess euthanasia (Arif et al., 2013).

\section{Anoxic stress tolerance test}

Swiss albino mice (18-25g) were used for forced for anoxic stress tolerance test. The animals were divided into 5 groups and all were treated as mentioned above in scheduled drug treatments. Conical flasks of $250 \mathrm{~mL}$ capacity were used for the study. These flasks were made airtight using rubber cork before beginning the experiment. Each animal was kept in the airtight vessel and time was noted using a stopwatch. The moment an animal showed first convulsion, it was removed immediately from the vessel and resuscitated if needed. The time duration from the entry of the animal in the hermetic (conical flask) vessel to the appearance of the first convulsion was taken as the time of "anoxic stress tolerance." The mean time to convulsion was recorded and animal was removed at onset of convulsion. The blood was collected through retroorbital puncture to estimate biochemical parameters like serum glucose and Corticosterone and blood cells (Puriet al., 2011).

\section{Antioxidant activity}

The free radical scavenging activity of $M$. cecropioides was determined by the DPPH assay described by Gulcin et al., (2010). 0.1 $\mathrm{ml}$ of the sample was added to $2 \mathrm{ml}$ of a $0.1 \mathrm{mM}$ solution of DPPH in methanol. The mixture was allowed to stand for $30 \mathrm{~min}$ in the dark and the absorbance measured at 517 $\mathrm{nm}$ using a UV spectrophotometer. Ascorbic acid was used as the positive control. Free radical scavenging activity from the sample was calculated according to the formula:

$\%$ of DPPH scavenging $=\left[1-\left(\mathrm{A}_{1} / \mathrm{A}_{\mathrm{O}}\right)\right] \mathrm{x}$ $100 \%$ 
Where $A_{O}$ was the absorbance of the control reaction and $A_{1}$ was the absorbance in the presence of the sample.

\section{Results and Discussion}

\section{Effect of the extract on forced swimming endurance stress test}

The effect of aqueous extract of $M$. cecropioides stem bark on the swimming survival time in forced swimming endurance stress test in rats is as shown in fig. 1, administration of diazepam $(1 \mathrm{mg} / \mathrm{kg})$ and the oral administration of the three different doses of aqueous extract $(100,200$ and $300 \mathrm{mg} / \mathrm{kg}$ ) of $M$. cecropioides is significant at $\mathrm{p}<0.05$ by

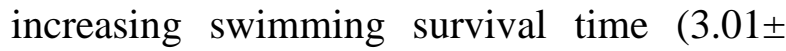
$0.92,3.34 \pm 0.18,3.73 \pm 0.98$ compared to the control group $2.25 \pm 0.08$ mins. Interestingly, all the doses of $M$. cecropioides are more potent with respect to lower dose of standard drug $(1 \mathrm{mg} / \mathrm{kg})$ of $2.8 \pm 0.37$ mins. All the doses were able to increase the swimming endurance when compared with animals who received normal distilled water.

During stress, (chronic cold restraint stress) releases various adrenal hormone such as catcholamines and glucocorticoids which makes the plasma glucose high due to excessive production of cortisol (Mulay, 2004). The treatment with the aqueous extract of stem bark of $M$. ceropioides significantly reduced the cold stress related hyperglycemias as the biochemical parameters on 7 th day as presented in table 1 below, revealed higher level of glucose in serum in the stressed control group (1) (78.83 \pm 0.28$)$ as compare to unstressed control (73.8 \pm 0.24$)$. In the standard group which is treated with diazepam $(1 \mathrm{mg} / \mathrm{kg})$, the serum glucose level was found to be $68.17 \pm 0.08$ and the oral administration of the three different doses of aqueous extract (100, 200 and $300 \mathrm{mg} / \mathrm{kg}$ ) of $M$. cecropioides are
$67.19 \pm 0.29,60 \pm 0.08$ and $61 \pm 0.96$. Also, Spleen constricts to release more blood cells (RBC and WBC) during stress, so their weights decrease in stress (Pawar and Hugar, 2012). This stress induced changes were significantly reversed by the test extract at lower and higher doses. The results of the urinary ascorbic acid obtained are in line with several studies which reported that the tissue levels of ascorbic acid decreased on application of stress (Kutlu and Forbes, 1993).

\section{Effect of the extract on chronic cold resistant stress test}

Hyper secretion of Corticosterone helps the maintenance of internal homeostasis through the process of gluconeogenesis (Singh et al., 2003). The treatment with the aqueous extract of stem bark of $M$. ceropioides significantly reduced the cold stress related hyperglycemias as the biochemical parameters on 7 th day as presented in table 2, revealed higher level of glucose in serum in the stressed control group (2) (106 \pm 0.07$)$ as compare to unstressed control $(72.6 \pm 0.88)$. In the standard group which is treated with diazepam $(1 \mathrm{mg} / \mathrm{kg})$, the serum glucose level was found to be $74.33 \pm 0.84$ and the oral administration of the three different doses of aqueous extract $(100,200$ and $300 \mathrm{mg} / \mathrm{kg})$ of M. cecropioides are $65.5 \pm 0.28,54.33 \pm 0.79$ and $61.73 \pm 0.95$.

Also, Spleen constricts to release more blood cells (RBC and WBC) during stress, so their weights decrease in stress (Pawar and Hugar, 2012). This stress induced changes were significantly reversed by the test extract at lower and higher doses. The results of the urinary ascorbic acid obtained are in line with several studies which reported that the tissue levels of ascorbic acid decreased on application of stress (Kutlu and Forbes, 1993). 
Table.1 The effect of Diazepam and M. cecropioides on biological parameters in forced swim test

\begin{tabular}{|l|l|l|l|l|}
\hline Groups & $\begin{array}{l}\text { Groups } \\
\text { Tags }\end{array}$ & $\begin{array}{l}\text { Giochemical/pathological parameters } \\
(\mathrm{mg} / \mathrm{dL})\end{array}$ & WBC & $\begin{array}{l}\text { 24hrs Urinary } \\
\text { Ascorbic Acid } \\
(\mu \mathrm{g} / \mathrm{kg} / 24 \mathrm{hrs})\end{array}$ \\
\hline $\mathbf{1}$ & $\begin{array}{l}\text { Stressed } \\
\text { Control }\end{array}$ & $78.83 \pm 0.28$ & $25429.3 \pm 0.59$ & $76.17 \pm 0.39$ \\
\hline $\mathbf{2}$ & $\begin{array}{l}\text { Unstressed } \\
\text { Control }\end{array}$ & $73.8 \pm 0.24$ & $22205 \pm 0.38$ & $121.67 \pm 0.19$ \\
\hline $\mathbf{3}$ & $\begin{array}{l}\text { Diazepam } \\
(1 \mathrm{mg} / \mathrm{kg})\end{array}$ & $68.17 \pm 0.08$ & $16125 \pm 0.09$ & $150.83 \pm 0.63$ \\
\hline $\mathbf{4}$ & $\begin{array}{l}\text { Test } \\
(100 \mathrm{mg} / \mathrm{kg})\end{array}$ & $67.19 \pm 0.29$ & $18718.33 \pm 0.42$ & $122.17 \pm 0.28$ \\
\hline $\mathbf{5}$ & $\begin{array}{l}\text { Test } \\
(200 \mathrm{mg} / \mathrm{kg})\end{array}$ & $60 \pm 0.08$ & $18183.83 \pm 0.38$ & $140.67 \pm 0.47$ \\
\hline $\mathbf{6}$ & $\begin{array}{l}\text { Test } \\
(300 \mathrm{mg} / \mathrm{kg})\end{array}$ & $61 \pm 0.96$ & $15911.69 \pm 0.71$ & $148.5 \pm 0.08$ \\
\hline
\end{tabular}

Data represent means \pm S.E of 6 rats during the 5minute test session. Comparisons were made by using a one-way ANOVA, followed by T-test $P<0.05$ was considered to be statistically significant

Table.2 The effect of Diazepam and M. cecropioides on biological parameters in Chronic Cold Resistant Stress Test

\begin{tabular}{|l|l|l|l|l|}
\hline & & \multicolumn{3}{|c|}{ Biochemical/haematological parameters } \\
\hline Group & Groups Tags & Glucose & WBC & $\begin{array}{l}\text { 24hrs } \\
\text { Ascorbic } \begin{array}{l}\text { Urinary } \\
(\mu \mathrm{g} / \mathrm{kg} / 24 \mathrm{hrs})\end{array}\end{array}$ \\
\hline $\mathbf{1}$ & $\begin{array}{l}\text { Unstressed } \\
\text { Control }\end{array}$ & $72.6 \pm 0.88$ & $17300 \pm 0.27$ & $121.38 \pm 0.41$ \\
\hline $\mathbf{2}$ & $\begin{array}{l}\text { Stressed } \\
\text { Control }\end{array}$ & $106 \pm 0.07$ & $19330 \pm 0.09$ & $73.26 \pm 0.17$ \\
\hline $\mathbf{3}$ & $\begin{array}{l}\text { Diazepam } \\
(1 \mathrm{mg} / \mathrm{kg})\end{array}$ & $71.33 \pm 0.84$ & $15030 \pm 0.52$ & $142.11 \pm 0.71$ \\
\hline $\mathbf{4}$ & $\begin{array}{l}\text { Test } \\
(100 \mathrm{mg} / \mathrm{kg})\end{array}$ & $65.5 \pm 0.28$ & $16381.6 \pm 0.77$ & $110.17 \pm 0.82$ \\
\hline $\mathbf{5}$ & $\begin{array}{l}\text { Test } \\
(200 \mathrm{mg} / \mathrm{kg})\end{array}$ & $54.33 \pm 0.79$ & $10451.67 \pm 0.28$ & $124.67 \pm 0.62$ \\
\hline $\mathbf{6}$ & $\begin{array}{l}\text { Test } \\
(300 \mathrm{mg} / \mathrm{kg})\end{array}$ & $61.73 \pm 0.95$ & $10350 \pm 0.82$ & $128.68 \pm 0.09$ \\
\hline
\end{tabular}

Data represent means \pm S.E of 6 rats during the 5minute test session. Comparisons were made by using a one-way ANOVA, followed by T-test $P<0.05$ was considered to be statistically significant. 
Fig.1 The effect of Diazepam and $M$. cecropioides on swimming times in rat using forced swim test

Effect on swimming times

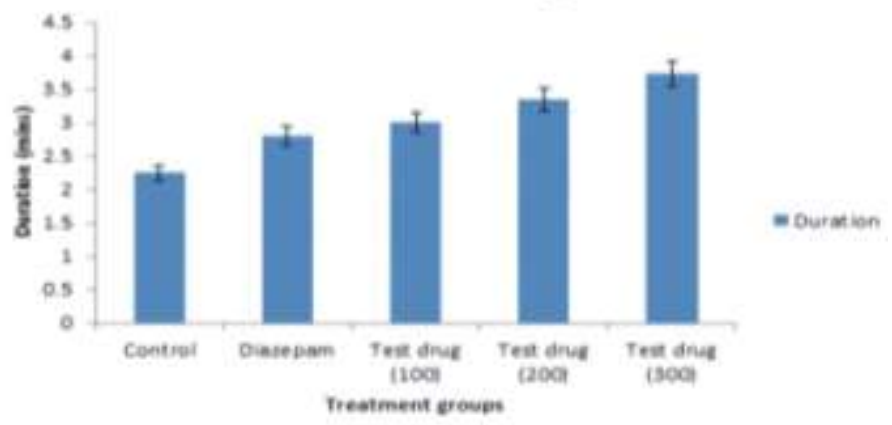

Data represent means \pm S.E of 6 rats during the 5 minute test session. Comparisons were made by using a one-way ANOVA, followed by T-test $P<0.05$ was considered to be statistically significant

Fig.2 The effect of Diazepam and M. cecropioides on swimming times in anorexia stress tolerance test

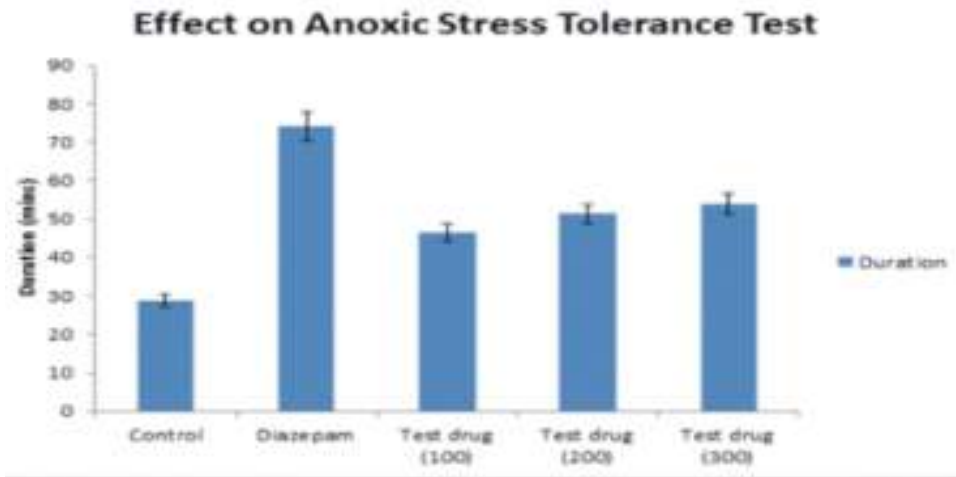

Data represent means \pm S.E of 6 rats during the 2 hrs test session. Comparisons were made by using a one-way ANOVA, followed by T-test $P<0.05$ was considered to be statistically significant

Fig.3 The antioxidant effect of aqueous extract of $M$. cecropioides using DPPH scavenging activity

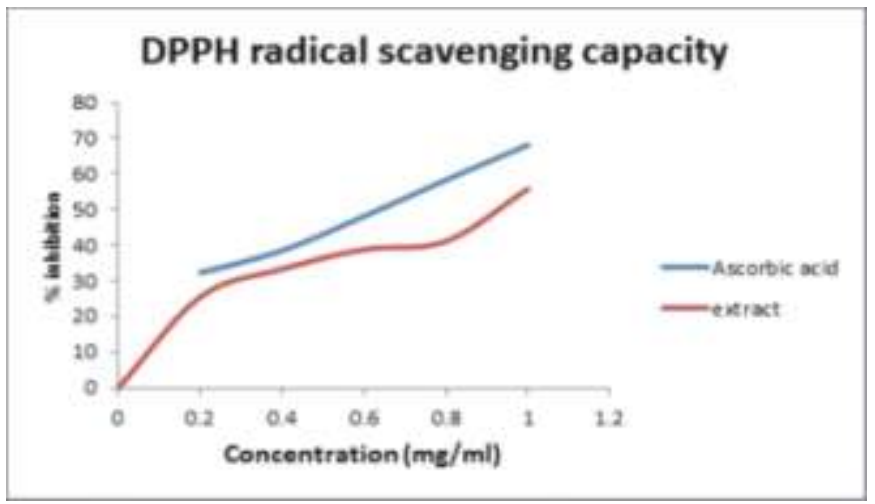

Effect of the extract on anoxic stress tolerance test

In anorexia stress tolerance test Group I (control) treated with distilled water $(1 \mathrm{~mL})$ was kept in hermetic vessel to for $28.80 \pm 0.38$ min. Animals treated with diazepam $(1 \mathrm{mg} / \mathrm{kg})$ standard survived in hermetic vessel for 74.26 min; the test groups animals with varying concentrations (100, 200, and $300 \mathrm{mg} / \mathrm{kg})$ 
survived in hermetic vessel for $46.48 \pm 0.28$, $51.28 \pm 0.09$ and $53.84 \pm 0.63 \mathrm{~min}$ respectively.

\section{Effect of the extract DPPH radical scavenging antioxidant activity}

$\mathrm{DPPH}$ is an oxidizing agent that can be reduced in the presence of an antioxidant, the stable DPPH can thus be used to quantify and compare the free radical scavenging capacities of different antioxidants (Yu, 2001). In this research, the aqueous extract the plant was found to possess impressive antioxidant capacity in a dose dependent manner comparable to that of ascorbic acid as depicted in figure 3 .

In conclusion, the aqueous extract showed impressive antistress potential and this present study present as far as is known, is the first report of the antistress (adaptogenic) activities of $M$. cecropioides, this findings have added to the many scientific proven biological activities of $M$. cecropioides.

\section{Acknowledgment}

To God be the glory, the authors wish to thank the management of Pax Herbal Clinic and Research Laboratories for the facilities offered and also grateful to prof. J.I Okogun and prof. B.A Ayinde for their support.

\section{References}

Adeneye AA, Ajagbonna OP, Ayodele OW (2007). Hypoglyceamic and antidiabetic activities of the aqueous and ethanolic extracts of Musanga cecropioides in normal and Alloxan induced diabetic rats. Fitoterapia 78(7-8): 502-505.

Adeneye, A.A., Ajagbonna, O.P., Mojiminiyi, F.B.O., Odigie, I.P., Etarrh, R.R., Ojobor, P.D., Adeneye, A.K., 2006. The hypotensive mechanisms for the aqueous extract of Musanga cecropioides stem bark in rats. J. Ethnopharmacol. 106, 203-207.

Ahmad. G, Yusuf Amin K.M, Khan A.N, The anti-stress activity of a gem-containing Unani formulation against diverse stressors, Ethanopharmacol J, Volume 59, 1998, Pages 187-192.

Ayinde BA, Omogbai EKI, Onwukaeme DN (2003). Pharmacognostic characteristics and hypotensive effect of the stem bark of Musanga cecropioides R.Br. (Moraceae). West Afr. J. Pharmacol. Drug Res. 19: 37-41.

Ayinde BA, Onwukaeme DN, Nworgu ZAM (2006). Oxytoxic effects of the water extract on Musanga cecropioides R. Brown (Moraecae) stem bark. Afr. J. Biotechnol. 5: 1350-1354.

Ayinde BA, Onwukaeme DN, Omogbai EKI (2007): Isolation and characterization of two phenolic compounds from the stem bark of Musanga cecropioides $\mathrm{R}$. Brown (Moraceae). Acta Pol. Pharm. 64: 183-185.

Ayinde, B.A., Omogbai, E.K.I. and Onwukaeme, D.N. (2009). Hypotensive effects of 3, 4-dihydroxybenzyaldehyde isolated from the stem bark of Musanga cecropioides. J of Pharmacognosy and Phytotherapy Vol. 1(1) pp. 004-009.

Bunkill, H.M. 1985. In: Farinhes, A.-D. (Ed.), The Useful Plants of West Tropical Africa, vol. 1, 2nd ed. Royal Botanical Gardens, Kew, pp.346-349.

Dongmo, A.B., Kamanyi, A., Bopelet, M. 1996. Saponins from the leaves of Musanga cecropioides (Cecropiaceae) constitute a possible source of potent hypotensive principles. Phytother. Res. 10, 23-27.

Gill L S. Ethnomedical uses of plants in Nigeria. Uniben Press, Benin City.1992: 170.

Gülçin, I., E. Kireçci, E. Akkemik, F. Topal and O. Hisar. 2010, Antioxidant and antimicrobial activities of an aquatic 
plant: duckweed (Lemna minor L.). Turkish Journal of Biology, 34 (2): 175:188.

Irvine FR (1961): Wood plants of Ghana. Oxford University Press, London pp.446-447.

Kamanyi A, Bopelet M, Tatchum TR (1992): Contractile effect of some extracts from the leaves of Musanga cecropioides (Cecropiaceae) on uterine smooth muscle of the rat. Phytother. Res. 6: 165-167

Kenjale R.D, Shah R.K, Sathaye S.S, Antistress and anti-oxidant effects of roots of Chlorophytum borivilianum, Indian J Exp Biol, Volume 45, 2007, Pages 974979

Kutlu HR, Forbes JM: Changes in growth and blood parameters in heat stressed broiler chicks in response to dietary ascorbic acid. Liverstock Prod Sci., 1993, 36: 335-350.

Lontsi D, Sondengam BL, Bodo B, Martin MT (1998a): Kalaic acid, a new Ursane - type Saponin from Musanga cecropioides. Planta Med. 64: 189-191

M. Arif, S. Fareed, T. Hussain, and M. Ali, "Adaptogenic activity of lanostane triterpenoid isolated from Carissa carandas fruit against physically and chemically challenged experimental mice," Pharmacognosy Journal, vol. 5, no. 5, pp. 216-220, 2013.

Mulay, M. Evaluation of herbals for adaptogenic activity. M. Tech Thesis, university of Mumbai, Mumbai India, 2004.

Orwa C, A Mutua, KindtR, Jamnadass R, S Anthony. 2009 Agroforestree Database: a tree reference and selection guide version 4.0

Pawar, V.S. and S. Hugar, "Adaptogenic activity of Trigonella foenumgraecum (Linn) seeds in rodents exposed to anoxia and immobilization stress," Asian Pacific Journal of Tropical Biomedicine, vol. 2, pp. S208-S211, 2012.

S. Puri, B. Kumar, J. Debnath et al., "Comparative pharmacological evaluation of adaptogenic activity of Holopteleainte grifolia and Withania somnifera," International Journal of Drug Development and Research, vol. 3, no. 1, pp. 84-98, 2011.

Selye, H. Syndrome produced by diverse nocuous agents. J. Neuropsy chiatry Clin Neurosci., 1998, 10: 230-231.

Singh, B., B.K. Chandan and D.K. Gupta, "Adaptogenic activity of a novel with anolide-free aqueous fraction from the roots of Withania somnifera Dun. (Part II)," Phytotherapy Research, vol. 17, no. 5, pp. 531-536, 2003.

$\mathrm{Yu} \mathrm{L}$. Free radical scavenging properties of conjugated linoleic acid. Journal Agricultural Food Chemistry. 2001; 49:3452- 3456

\section{How to cite this article:}

Tunde A. Owolabi, K.C. Ezenwa, E.Y. Olayioye, O.C. Iyorhibe, E. Amodu, O.F. Aferuan, P.C. Okubor, B.A. Ayinde and Okogun, J.I. 2019. Adaptogenic (Anti-Stress) Effect of Aqueous Musanga cecropioides (Urticaceae). Int.J.Curr.Microbiol.App.Sci. 8(10): 2558-2565. doi: https://doi.org/10.20546/ijcmas.2019.810.296 